\title{
ОСОБЛИВОСТІ ЖИТТЕСТІЙКОСТІ ТА АДАПТИВНОСТІ СТУДЕНТІВ У КРИЗОВИХ СИТУАЦІЯХ
}

\section{Кордунова Наталія}

Волинський національний університет імені Лесі Українки м. Луцьк, Україна, natalia300319701@gmail.com

ORCID: https: //orcid.org/0000-0002-4683-0929

\section{Мудрак Ігор}

Волинський національний університет імені Лесі Українки

м. Луцьк, Україна, sim851@ukr.net

ORCID: https: //orcid.org/0000-0002-9003-0435

\section{Дмитріюк Наталія}

Волинський національний університет імені Лесі Українки

м. Луцьк, Україна, dm.ns@ukr.net

ORCID: https: //orcid.org/0000-0001-8055-0237

Мета. У статті здійснено теоретичний аналіз психологічних особливостей життєстійкості та адаптивності студентів у кризових ситуаціях.

Методи. Для реалізації мети дослідження були використані методи теоретичного наукового пошуку: аналіз, синтез, узагальнення. Для проведення емпіричного дослідження - «Тест життєстійкості» S. Maddi (адаптація Д. Леонтьєва, О. Рассказової), опитувальник «Адаптивність» А. Г. Маклакова, С. В. Чермяніна. В дослідженні взяли участь 80 студентів першого курсу Волинського національного університету імені Лесі Українки.

Результати. Аналіз праць українських та закордонних науковців засвідчує, що життєстійкість є необхідним елементом адаптаційного потенціалу особистості, завдяки якому людина чинить опір негативним впливам середовища, стає впевненою й рішучою у власних діях. Життєстійкість сприяє збереженню здоров'я та підтриманню оптимального рівня працездатності й активності в кризових ситуаціях.

Висновки. Життєдіяльність - це важлива складова адаптивності студентів

ISSN 2308-3743 (Online), ISSN 2227-1376 (Print)

(C) Кордунова Н., Мудрак I., Дмитріюк Н., 2021. Ця стаття відкритого доступу на умовах CC BY-NC 4.0 
у кризових ситуаціях. Доведено, що адаптивність як стійка властивість особистості є внутрішнім підгрунтям спроможності до пристосування в будьяких умовах життєдіяльності та готовності до взаємодії з середовищем.

Перспективи подальших досліджень - у вивченні психологічних особливостей та їх взаємозв'язку 3 іншими властивостями особистості, що сприятимуть ефективнішому функціонуванню особистості в мінливих умовах сьогодення.

Ключові слова: життєстійкість, адаптація, адаптивність, особистість, студентський період життя.

Kordunova Natalia, Mudrak Igor, Dmytriiuk Natalia. Features of vitality and adaptability of students in crisis situations.

Purpose. The article provides a theoretical analysis of the psychological features of vitality and adaptability of students in crisis situations.

Methods. To realize the purpose of the study, the following methods of theoretical scientific research were used: analysis, synthesis, generalization. To conduct an empirical study - «Test of viability» S. Maddi (adaptation of D. Leontiev, O. Rasskazova), questionnaire «Adaptability» A.G. Maklakova, C.B. Chermyanin. The study involved 80 first-year students of Volyn Lesya Ukrainka National University.

Results. The analysis of Ukrainian and foreign works allows us to state that vitality is a necessary element of the adaptive potential of the individual; allows a person to resist the negative effects of the environment, provides confidence and determination in their own actions, helps to maintain health and maintain optimal levels of efficiency and activity in crisis situations.

Conclusions. In general, we can conclude that life is an important component of student adaptability in crisis situations. It is proved that adaptability as a stable property of the individual is the internal basis of the ability to adapt to any living conditions and willingness to interact with the environment.

The prospects for further research are seen in the study of psychological features in their relationship with other personality traits that will contribute to more effective functioning of the individual in the changing conditions of today.

Keywords: vitality, adaptation, adaptability, personality, student period of life.

Кордунова Наталия, Мудрак Игорь, Дмытриюк Наталия. Особенности жизнестойкости и адаптивности студентов в кризисных ситуациях.

Цель. В статье осуществлен теоретический анализ психологических особенностей жизнестойкости и адаптивности студентов в кризисных ситуациях.

Методы. Для реализации целей исследования были использованы методы теоретического научного поиска: анализ, синтез, обобщение. Для проведения эмпирического исследования - «Тест жизнестойкости» S. Maddi (адаптация Д. Леонтьева, О. Рассказовой), опросник «Адаптивность» А. Г. Маклаковой, С. В. Чермянина. В исследовании приняли участие 80 студентов первого курса 
Волынского национального университета имени Леси Украинки.

Результаты. Анализ украинских и зарубежных работ позволяет утверждать, что жизнестойкость является необходимым элементом адаптационного потенциала личности; позволяет человеку оказывать сопротивление негативным воздействиям среды, придает уверенности и решительности в личных действиях, способствует сохранению здоровья и поддержанию оптимального уровня работоспособности и активности в кризисных ситуациях.

Выводы. Жизнестойкость - это важная составляющая адаптивности студентов в кризисных ситуациях. Доведено, что адаптивность как устойчивое свойство личности является внутренней основой способности к приспособлению в любых условиях жизнедеятельности и готовности к взаимодействию со средой.

Перспективы дальнейших исследований видим в изучении психологических особенностей их взаимосвязи с другими свойствами личности, которые будут способствовать более эффективному функционированию личности в изменяющихся условиях настоящего.

Ключевые слова: жизнестойкость, адаптация, адаптивность, личность, студенческий период жизни.

Вступ. Сучасне життя характеризується надзвичайною потребою людини в адаптації до складних і швидкозмінних соціальних умов. Сьогодні суспільство знаходиться на такому етапі розвитку, коли діє багато негативних чинників, здатних викликати стреси та перевантаження. Водночас соціальні кризові явища зумовлюють підвищення рівня життєстійкості та адаптивності особистості. Втім, потрапляючи в складні життєві ситуації, людина не завжди може знайти ефективне їх розв'язання.

В умовах швидких змін освіта покликана підготувати молодь до життя та діяльності в нинішньому суспільстві. Однак у період нестабільності в державі багато факторів знижують опір студентів до подолання життєвих труднощів у період навчання в ЗВО. Науковий і практичний інтерес все більше викликає проблема дослідження психологічних особливостей життєстійкості та адаптивності студентів.

Студентський період життя характеризується розвитком самосвідомості, вольової та мотиваційної сфери. Саме в цьому віці завершується розвиток життєстійкості особистості, яка допомагає чинити опір негативним впливам середовища. Проте багато студентів відчувають труднощі в конструктивному вирішенні проблеми. А, отже, головною метою стає завдання навчити студентів долати 
проблеми та протистояти труднощам. Тому актуальним стає вивчення життєстійкості як інтегративної характеристики адаптивності особистості в кризових ситуаціях.

Мета цього дослідження полягає в теоретичному аналізі й емпіричному вивченні особливостей прояву адаптивності та життєстійкості студентів у кризових ситуаціях.

Аналіз наукових праць Л. Анциферової, Ф. Василюка, С. Максименка, Т. Титаренко та ін. свідчить про зростання наукового інтересу до проблеми вивчення різних аспектів поведінки, спрямованої на подолання кризових для особистості ситуацій.

Л. Анциферова дотримується думки, що для визначення ступеня певної події обов'язково потрібно враховувати особистісний контекст, оскільки для кожної людини різні події будуть сприйматися по-різному та різною мірою міститимуть у собі стресогенні фактори (Анциферова, 1994).

С. Максименко стверджує, що центральним моментом життєвих випробовувань $\epsilon$ особистісна криза, яка детермінується обставинами життя, соціальними ситуаціями та внутрішніми особистісними конфліктами (Максименко, 2017).

Як зазначає Ф. Василюк, критичну ситуацію слід розуміти як таку, що унеможливлює реалізацію життєво важливих потреб, мотивів, цінностей (Василюк, 1995).

Т. Титаренко кризу визначає як тривалий і водночас внутрішній конфлікт, котрий передбачає пошук нових можливостей реконструкцій життєвого світу. Переживання людиною кризи тісно пов'язане зі ступенем усвідомлення кризового стану. Деякі люди мають змогу зізнатися собі в гострих проблемах. Інші, не помічаючи наближення кризової ситуації, намагаються уникнути необхідності усвідомлення життєвих обставин (Титаренко, 2006).

Дослідники Л. Бурлачук, О. Коржова та С. Варбан окреслюють основні підходи до вивчення психологічних аспектів складних життєвих ситуацій, які потребують від людини дій, що перевершують iii адаптивні можливості та ресурси. Дослідники наголошують, що ситуація передбачає активну позицію самої людини щодо життєвих обставин, певне їх осмислення, переживання (Бурлачук, Коржова, 1998; Варбан, 2009).

На думку К. Маннапової, життєві події викликають в особистості різні реакції й організовують дійсність відповідно до розміру 
проблеми. Якщо особистість постійно обирає звичні способи реагування на важкі життєві ситуації, виходячи 3 прагнення до комфорту та безпеки, то в майбутньому це призводить до життєвого застою особистості (Маннапова, 2019).

Складні життєві ситуації вимагають від особистості високого рівня життєстійкості. Одним із особистісних ресурсів конструктивного подолання кризової ситуації та відновлення внутрішньої рівноваги є життєстійкість.

Дослідження S. Maddi продемонстрували, що життєстійкість є особистісною характеристикою, яка $є$ загальною мірою психічного здоров'я людини та відображає три життєві установки: включеність, впевненість у можливості контролю над подіями, а також готовність до ризику (Maddi, 2006).

На думку А. Фомічової, життєстійкість - це інтегральна риса особистості, відповідальна за успішність подолання життєвих труднощів. Життєстійкість допомагає чинити опір негативним впливам середовища, підвищує стресостійкість людини, дає змогу прогнозувати бажане майбутнє (Фомічова, 2012).

Життєстійкість являє собою систему переконань про себе, про світ, про відносини зі світом. Вона характеризує міру здатності особистості витримувати стресові ситуації, зберігаючи внутрішню збалансованість і не знижуючи успішність діяльності. Життєстійкість - це важливий особистісний ресурс, який сприяє подоланню стресів і досягненню високого рівня психічного та фізичного здоров'я.

Життєстійкі люди володіють трьома важливими рисами: вони приймають дійсність такою, якою вона $\epsilon$; глибоко переконані, що життя має сенс (основу для цього переконання часто створює перевага тих чи інших цінностей), а також вирізняються вмінням імпровізувати та нетривіально вирішувати проблеми.

Ця властивість особистості складається 3 трьох порівняно автономних компонентів: залученість, контроль, прийняття ризику. Виразність цих компонентів перешкоджає виникненню внутрішньої напруги в стресових ситуаціях завдяки стійкому опануванню стресами і сприйняттю їх як менш значущих.

Людина 3 розвиненим компонентом залученості отримує від власної діяльності задоволення, почуває себе цінною та важливою.

Компонент контролю передбачає впевненість у тому, що боротьба дає змогу впливати на результати того, що відбувається - 
навіть у тому разі, коли успіх справи не гарантовано. Людина, яка має розвинений компонент контролю, переконана, що сама обирає власну діяльність та свій шлях (Maddi, 2006).

С. Кравчук розглядає життєстійкість як психологічний феномен, який на змістовно-структурному рівні $\epsilon$ складною інтегральною характеристикою особистості та містить такі психологічні компоненти: емоційний, когнітивний, моральний, вольовий i поведінковий. На процесуально-динамічному рівні аналізу життєстійкість виступає як особистісний стиль. На функціональному рівні - це чинник адаптаційного ресурсу творчого потенціалу особистості, її особистої зрілості (Кравчук, 2018).

Аналіз наукових підходів до тлумачення життєстійкості підтверджує, що вона $є$ важливим компонентом розвитку особистості. Саме ця властивість дає змогу людині чинити опір негативним впливам середовища, надає впевненості та рішучості у власних діях, сприяє збереженню здоров'я та підтриманню оптимального рівня працездатності й активності в стресових умовах.

Життєстійкість пов'язана 3 розвитком психологічних якостей, серед яких важливе місце займає адаптивність особистості.

Поняття «адаптивність особистості» розглядають як полісистемну функціонально-структурну властивість інтегральної індивідуальності, що визначається сукупністю іiі різнорівневих індивідуальних характеристик, які проявляються в показниках продуктивності й гомеостатичності (Санникова, Кузнецова, 2009). Науковці виокремлюють такі компоненти адаптивності особистості: «розуміння смислу майбутніх подій; постійно оновлювані адекватні уявлення про майбутні зміни в особистому та суспільному житті; адекватна оцінка власних актуальних та потенційних можливостей; готовність здійснювати внутрішні та зовнішні дії для адаптації до змін; переживання індивідуальних змін і стресових ситуацій як тимчасових або необхідних для досягнення мети труднощів; ставлення до адаптації як до діяльності, необхідної для отримання певних результатів; відповідальність за свої можливі дії; відкритість, гнучкість і терпимість до нового; комунікативна компетентність» (Симаева, 2006).

Адаптивність до стресу В. Розов розглядає в єдності таких структурних компонентів як: здатність до адаптивного мислення; 
оптимістичний когнітивний стиль; здатність встановлювати та розвивати взаємини підтримки; здатність до впевненої поведінки; здатність до самоорганізації часу життя; здатність до адаптивного сну та сновидінь; здатність до управління психофізіологічними станами; здатність до підтримки оптимального фізичного стану (Розов, 2012).

О. Маклаков у межах концепції особистісного адаптаційного потенціалу виділяе такі компоненти адаптивності особистості: нервово-психічна стійкість, комунікативні особливості, моральна нормативність (Маклаков, 2001).

Вчені О. Санникова, О. Кузнецова адаптивність розглядають як багаторівневе цілісне утворення (містить формально-динамічний, змістовно-особистісний та соціально-імперативний рівні). Кожен із виділених у структурі адаптивності рівнів можна представити низкою репрезентативних ознак. Серед них основними, базовими є показники формально-динамічного та якісного рівнів - як такі, що, по-перше, належать до характеристик індивідуальності, темпераменту, тобто саме на їх засаді формуються змістовні характеристики адаптивності (здатність до свідомої регуляції адаптивних процесів, вольової регуляції поведінки та діяльності особистості, схильність до вибору певного соціального середовища, до якого адаптується особистість, вибору певних стратегій адаптації в типових соціальних ситуаціях тощо); по-друге, формально-динамічні та якісні ознаки містять у собі психологічну сутність адаптивності (Санникова, Кузнецова, 2009).

Враховуючи наші попередні дослідження, ми зосереджуємо свою увагу на вивченні адаптивності саме в особистісному аспекті; розглядаємо іiі як стійку властивість, пов'язану 3 виявом життестійкості.

Методи та процедура дослідження. Дослідницьку вибірку склали студенти першого курсу (80 осіб) Волинського національного університету імені Лесі Українки. Для досягнення мети та завдань дослідження були використані методи теоретичного наукового пошуку: аналіз, синтез, узагальнення, а також «Тест життєстійкості» S. Maddi (адаптація Д. Леонтьєва, О. Рассказової), опитувальник «Адаптивність» А. Г. Маклакова, С. В. Чермяніна.

Обговорення результатів. Студентський період життя характеризується своїми закономірностями та віковими суперечностями формування особистості. Студент як суб'єкт модернізації системи вищої освіти перебуває в ситуації підвищеної 
стресогенності. Навіть маючи особистісні ресурси, під час стресових ситуацій молодь виявляє власну неспроможність розв'язати проблему та впоратися 3 вимогами таких ситуацій. Втім, саме в період студентства відбувається формування життєстійкості до подолання кризових ситуацій.

Життєстійкістю можна вважати певний необхідний адаптаційний потенціал особистості, що є вагомим у студентському віці, оскільки він сприяє професійному та особистісному зростанню молодої людини.

Варто зауважити, що для студентської молоді очевидною $є$ проблема, яка зумовлена протиріччям між соціальним середовищем, яке склалося i яке вимагає максимальної адаптації, вмінням ефективно впоратися зі стресовими ситуаціями й мінливими умовами життя та недостатнім рівнем життєстійкості, незнанням або невмінням користуватися особистісним потенціалом для подолання життєвих труднощів. Тож постає необхідність дослідження психологічних особливостей життєстійкості й адаптивності студентів та пошуку шляхів ії підвищення.

3 метою дослідження особливостей прояву життєстійкості в студентів ми використали «Тест життєстійкості» S. Maddi в адаптації Д. Леонтьєва, О. Рассказової (Леонтьєв, Рассказова, 2008). Діагностика засвідчила, що компоненти життєстійкості досліджуваних студентів проявляються на високому, середньому та низькому рівнях. За компонентом «залученість» досліджувані демонструють $25,3 \%$ високий, 58,2\% середній та $16,5 \%$ низький рівні. Це свідчить про те, що в більшості опитаних студентів переважають високий і середній рівень цього критерію. Висока їх виразність перешкоджає виникненню внутрішньої напруги в кризових ситуаціях, допомагає зберегти оптимальну працездатність та активність. Проте частина студентів має низький рівень виразності цього компоненту.

Компонент «контролю» на середньому рівні виразності притаманний 44,9\% студентам. 32,1\% досліджуваних мають високий, a 13,0\% - низький рівень контролю. Це свідчить про те, що більшість досліджуваних можуть безпосередньо впливати на події в своєму житті, самостійно приймати рішення навіть тоді, коли успіх справи не гарантований. Ця характеристика також властива студентам iз високим рівнем виразності цього компоненту. 3 іншого боку студенти 3 низьким рівнем можуть бути невпевненими у власних 
силах, почувають себе в напружених ситуаціях безпомічними.

Третій компонент - «прийняття ризику» на високому рівні притаманний 31,6\% досліджуваним. Ці досліджувані переконані в тому, що все, що з ними відбувається, сприяє їхньому розвитку завдяки здобутому досвіду. Вони готові йти до кінця навіть тоді, коли успіх справи не гарантований. 46,5\% досліджуваних демонструють середній рівень. За цим компонентом студенти вагаються в прийнятті правильних рішень. I 21,9\% студентів мають низький рівень виразності цього компоненту; вони схильні до уникнення ризикових ситуацій, прагнуть отримати надійні аргументи на користь успішності, перш ніж приступити до будь-якої справи.

Отож, отримані результати компонентів життєстійкості показують, що більше як половина досліджуваних студентів можуть добре впоратися 3 труднощами та ефективно скористатися внутрішніми ресурсами. Проте частина досліджуваних важко переживає труднощі та зміни в кризових ситуаціях.

Під час вивчення особливостей адаптивності (опитувальник «Адаптивність» А. Г. Маклакова, С. В. Чермяніна) досліджувалися такі показники як нервово-психічна стійкість, поведінкова регуляція, адекватна самооцінка та реальне сприйняття дійсності, комунікативний потенціал, адаптивні здібності, моральна нормативність. $\mathrm{P}$

За показником «нервово-психічна стійкість» 47,5\% досліджуваних демонструють середній, $16,1 \%$ високий та 26,9\% низький рівень.

За показником «поведінкова регуляція» 42,5\% досліджуваних демонструють середній, 39,1\% високий та 18,4\% низький рівень.

За показником «адекватна самооцінка» найбільша частина досліджуваних має середній рівень - 51,2\%, 18,9\% - високий, 21,9\% низький рівень.

За показником «реальне сприйняття дійсності» високий рівень виявлено в 34,0\% досліджуваних, середній у 42,3\%, низький у 23,7\% студентів.

За показником «моральна нормативність» високий рівень виявлено в 30,0\% досліджуваних, середній у 46,5\%, низький у 23,5\%.

За показником «комунікативний потенціал» високий рівень виявлено в 39,3\% досліджуваних, середній у 45,7\%, низький у 15,0\%.

За показником «адаптивні здібності» високий рівень виявлено в 
28,6\% досліджуваних, середній у 39,8\%, низький у $31,6 \%$.

Узагальнення даних засвідчує, що в досліджуваних переважає середній рівень адаптаційного потенціалу.

Згідно 3 результатами дослідження, студенти 3 високим рівнем нервово-психічної стійкості та поведінковою регуляцією мають адекватну самооцінку та реальне сприйняття дійсності, високий розвиток комунікативних здібностей та моральної нормативності.

Студентам із середнім рівнем адаптаційного потенціалу властиві ознаки різних акцентуацій, які в звичних умовах частково компенсовані й можуть з'являтися зі зміною діяльності, тому успішність їхньої адаптації залежить від зовнішніх умов середовища.

Студентам із низьким рівнем адаптаційного потенціалу властива нервово-психічна стабільність, поведінкова регуляція, відсутність адекватної самооцінки та реального сприйняття дійсності, низький рівень комунікативного потенціалу й моральної нормативності.

Дослідження показує, що адаптивність має певну специфіку в пристосуванні до діяльності в кризових умовах. Вона виявляється на середньому рівні розвитку цієї властивості загалом та в певному якісно-кількісному сполученні іï показників. Той факт, що більшість досліджуваних продемонстрували середні показники адаптивності, на нашу думку, свідчить про те, що розвиток саме цієї властивості $\epsilon$ однією 3 передумов пристосування цих осіб до складних умов діяльності, які пов'язані зі значними труднощами, що викликають мобілізацію їхніх адаптивних здібностей. Отримані дані підтверджують, що адаптивність - це така властивість особистості, яка має важливе значення для адаптації особистості до діяльності та професійної життєстійкості в кризових умовах.

Згідно з критерієм Пірсона встановлено, що існує статистично значущий зв'язок між показниками життєстійкості та показниками адаптивності. Підтверджено, що всі показники життєстійкості мають зворотний зв'язок із такими показниками адаптивності як «нервовопсихічна стійкість» на рівні значущості (ч=0,478, p $\geq 0,01$ ), «поведінкова регуляція» (ч=0,357, $\mathrm{p} \geq 0,01)$, «адекватна самооцінка»

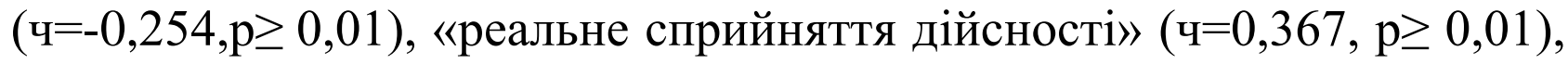
«комунікативний потенціал» (ч= -0,234, $\mathrm{p} \geq 0,01)$, «адаптаційні здібності» (ч=0,151, $\mathrm{p} \geq 0,01)$, «моральна нормативність» (ч=0,277, $\mathrm{p} \geq 0,01)$.

Це свідчить про те, що студенти, які виявляють високий рівень 
нервово-психічної стійкості та поведінкової регуляції, високу адекватну самооцінку та реальне сприйняття дійсності, $\epsilon$ самостійними та адекватно реагують на зміни навколишнього середовища, впевнено почувають себе в незвичних ситуаціях.

Отже, життєстійкість є необхідним елементом адаптаційного потенціалу особистості. Перевага високого та середнього рівнів життєстійкості в студентів-першокурсників пов'язані зі здатністю до використання активної поведінки для пошуку можливих способів подолання труднощів у кризових ситуаціях.

Висновки та перспективи. Теоретичний аналіз проблеми показав значущу роль життєстійкості та адаптивності у формуванні особистості. Більшість учених життєстійкість розуміють як здатність особистості витримувати стресові ситуації та зберігати водночас внутрішню збалансованість без зниження успішності діяльності. Життєстійкість допомагає людині чинити опір негативним впливам середовища, надає впевненості та рішучості у власних діях, сприяє збереженню здоров'я та підтриманню оптимального рівня працездатності й активності в кризових умовах.

Отримані дані дають підстави розглядати адаптивність як властивість особистості, що має важливе значення для адаптації особистості до діяльності в екстремальних умовах, iї довготривалості та професійної надійності. Адаптивність - це полісистемна функціонально-структурна властивість інтегральної індивідуальності, що визначається сукупністю іiі різнорівневих індивідуальних характеристик, які виявляються в показниках іiі продуктивності. Адаптивність особистості займає повноцінне місце серед відомих у психології психологічних властивостей, що забезпечують адаптацію до діяльності в кризових умовах.

Визначено, що життєстійкість розглядається як необхідний адаптаційний потенціал особистості, що є надзвичайно вагомим саме в студентському віці. В досліджуваних студентів переважає високий та середній рівень основних показників як життєстійкості, так і адаптивності. Однак третина досліджуваних демонструє низький рівень показників, що свідчить про недостатність досвіду та навичок активного вирішення проблем. Це може спровокувати механізм уникнення і значно знижує можливості адаптивності особистості в кризових ситуаціях.

Доведено, що життєстійкість має зворотний зв'язок із такими 
показниками адаптивності як нервово-психічна стійкість, поведінкова регуляція, адекватна самооцінка, реальне сприйняття дійсності, моральна нормативність.

Отже, життєстійкість - необхідний елемент адаптивності особистості. Перевага високого та середнього рівнів життєстійкості в студентів пов'язана 3 готовністю до змін, здатністю використання активної поведінки для пошуку можливих способів подолання кризових ситуацій. Чим нижчий рівень життєстійкості, тим слабше проявляються ці показники, що може призводити до їх уникнення i значно знижує можливість адаптивності особистості.

Перспектива дослідження - в розгорнутому вивченні психологічних особливостей життєстійкості та їх взаємозв'язку 3 іншими властивостями особистості, що сприятимуть ефективнішому функціонуванню особистості в мінливих умовах сьогодення.

\section{Література}

1. Анциферова, Л. И. (1994). Личность в трудных жизненных условиях: переосмысление, преобразование ситуаций и психологическая защита. Психологический журнал, 5, 3-18.

2. Бурлачук, Л.Ф., Коржова, Е. Ю. (1998). Психология жизненных ситуаций. Москва : Рос. педагог. агенство, 177-209.

3. Варбан, Є. О. (2009). Стратегії подолання життєвих криз в юнацькому віці. Автореф. дис. ... канд. психол. наук : 19.00.07. Київ.

4. Василюк, Ф. Е. (1995). Жизненный мир и кризис. Психологический журнал, 3. Т. 16, 90-101.

5. Кравчук, С. (2018). Психологічні особливості життєстійкості студентів та їх ставлення до активної участі в політичному житті суспільства в умовах воєнного конфлікту. Психологічні виміри, економіки, управління. Львів, Т. 12, 27-38.

6. Леонтьев, Д. А., Рассказова, Е. И. (2006). Тест жизнестойкости. Москва: Смысл.

7. Маклаков, А. (2001). Личностный адаптационный потенциал: его мобилизация и прогнозирование в екстремальных условиях. Психологический журнал, 1. Т. 22, 16-24.

8. Максименко, С. Д., Кузікова, С. Б., Зливка В. Л. (2017). Особистість в кризових ситуаціях: психологічна теорія і практика. Суми: Вид-во Сум ДПУ імені А. С. Макаренка.

9. Маннапова, К. (2019). Роль життєстійкості у подоланні складних життєвих ситуацій. Теорія і практика сучасної психології,1. Т. 2, 75-78.

10. Розов, В.И. (2012). Психология ектремальных ситуаций: адаптивность к стрессу и психологическое обеспечение: научно-практическое пособие. Киев, КНТ; Самит-книга. 
11. Санникова, О. П. (2017). Системный анализ адаптивности личности: монография. Одесса: Издательство ВМВ.

12. Санникова, О. П., Кузнецова, О. В. (2009). Адаптивность личности. Одесса: Издатель Н. П. Черкасов.

13. Симаева, И. Н. (2006). Психология адаптации личности к изменениям жизнедеятельности. Автореф. дисс. ... докт. психол. наук. Санкт-Петербург.

14. Титаренко, Т. М. (2006). Потенціал подолання складних життєвих обставин. Наукові студї із соиіальної та політичної психологї̈: зб. статей, 13 (16). Київ.

15. Фомичова, А.Н. (2012). Жизнестойкость личности: монография. Москва: МПГУ.

16. Maddi, S. (2006). Hardiness: The courage to grow from stresses. The joumal of Positive Psychology, T. 1, 160-168.

17. Reupert, A. (2020). Change and (the need for) adaptability: the new normal. Advances in Mental Health, 18:2, 91-93, DOI: https://doi.org/10.1080/18387357.2020.1792633

18. Stockinger, K., Rinas, R., Daumiller, M. (2021). Student adaptability, emotions, and achievement: Navigating new academic terrains in a global crisis. $\begin{array}{llll}\text { Learning and Individual Differences, } & 90, & 102046 .\end{array}$ https://doi.org/10.1016/j.lindif.2021.102046

\section{References}

1. Antsyferova, 1. I. (1994). Lichnost v trydnykh zhyznennykh usloviyakh: pereosmyslenie, preobrazovaniie situatsyi i psikhologicheskaya zashchita [Personality in difficult living conditions: rethinking, transformation of situations and psychological protection]. Psykhologicheskiy zhurnal - Psychological Journal, 5, 318 [in Russian].

2. Burlachuk, L. F., Korzhova, E. Y. (1998). Psykhologiya zhiznennykh situatsiy [Psychology of life situations]. Moscow: Ros. pedagog. agenstvo, 177-209. [in Russian].

3. Varban, Y. O. (2009). Strategiyi podolannia zhyttevykh kryz v yunatskomy vitsi [Strategies for overcoming life crises in adolescence]. avtoref. dys. ... kand.psyhk.nauk : 19.00.07. Kyiv. [in Ukrainian].

4. Vasyliuk, F. E. (1995). Zhyznennyi mir i krizis [Life and crisis]. Psykhologicheskiy zhurnal, 3. T. 16, 90-101. [in Russian].

5. Kravchuk, S. (2018). Psykhologichni osoblyvisti zhyttestiikosti studentiv ta yih stavlennia do aktyvnoyu uchasti $\mathrm{v}$ politychnomy zhytti suspilstva $\mathrm{v}$ ymovakh voyennogo konflikty [Psychological features of students' resilience and their attitude to active participation in the political life of society in conditions of military conflict]. Psykhologichni vymiry, ekonomiky, ypravlinnya - Psychological dimensions, economics, management. Lviv, T. 12, 27-38. [in Ukrainian].

6. Leontiev, D. A., Rasskazova, E. I. (2006). Test zhysniestoykosti [Viability test]. Moskva: Smysl. [in Russian]. 
7. Maklakov, A. (2001). Lychnosniy adaptatsionnyi potentsial: yego mibilisatsyia i prognozirovaniye $\mathrm{v}$ ekstremalnykh ysloviyakh [Personal adaptation potential: its mobilization and forecasting in extreme conditions]. Psykhologicheskiy zhurnal, 1(22), 16-24 [in Russian].

8. Maksymenko, S. D., Kuzikova, S. B., Zlyvka V. L. (2017). Osoblyvist v kryzovykh situatsiyah: psykhologichna teoriia i praktyka: monographiya [Personality in crisis situations: psychological theory and practice: a monograph]. Sumy: Vyd-vo Sumy Makarenko DPU [in Ukrainian].

9. Mannapova, K. (2019). Rol zhyttestiikosty y podolanni skladmykh zhyttevykh situatsiy [The role of vitality in overcoming difficult life situations]. Teoria $i$ praktyka sychasnoi psykhologiyi - Theory and practice of modern psychology, 1. T. 2, 75-78. [in Ukrainian].

10. Rozov, V. I. (2012). Psikhologiya ekstremalnykh situatsiy: adaptivnost k stressu i psikhologicheskoye obespecheniye: nauchno-prakticheskoye posobiye [Psychology of extreme situations: adaptability to stress and psychological support: a scientific and practical guide]. Kiev, KNT; Sammit-kniga. [in Ukrainian].

11. Sannikova, O. P. (2017). Sistemniy analyz adaptivnosty lichnosti: monographiya [System analysis of personality adaptability]. Odessa: Izdatelstvo VMV [in Ukrainian].

12. Sannikova, O. P., Kuznetsova, O. V. (2009). Adaptivnost lichnosti [Personality adaptability]. Odessa: Izdatel N. P. Cherkasov [in Ukrainian].

13. Simayeva, I. N. (2006). Psikhologiya adaptatsyi lichnosti k izmeneniyam zhyznedeyatelnosti [Psychology of adaptation of the person to changes of vital activity]: Extended abstract of Doctor's thesis. Sankt-Peterburg. [in Russian].

14. Titarenko, T. M. (2006). Potentsial podolannya skladnykh zhyttevykh obstavyn [Potential to overcome difficult life circumstances]. Naukovi studii iz sitsialnoyi ta politychnoyi psykhologiyi: $z b$. stattei - Scientific studies in social and political psychology, 13 (16). Kyiv. [in Ukrainian].

15. Fomichova, A. N. (2012). Zhyznestoikost lychnosti [Vitality of the person]. Moskva: MPGU. [in Russian].

16. Maddi, S. (2006). Hardiness: The courage to grow from stresses. The joumal of Positive Psychology, T. 1, 160-168.

17. Reupert, A. (2020). Change and (the need for) adaptability: the new normal. Advances in Mental Health, 18:2, 91-93, DOI: https://doi.org/10.1080/18387357.2020.1792633

18. Stockinger, K., Rinas, R., Daumiller, M. (2021). Student adaptability, emotions, and achievement: Navigating new academic terrains in a global crisis. $\begin{array}{llll}\text { Learning and Individual Differences, } & 902046 .\end{array}$ https://doi.org/10.1016/j.lindif.2021.102046

Received: 24.08.2021

Accepted: 25.09.2021 